\title{
POSITION
}

\section{SOCIALE TEKNOLOGIER}

FRA MAGTKRITIK TIL MÆEGTIGGØRELSE

\section{CHARLOTTE BREDAHL JACOBSEN OG SOFIE DANNESKIOLD- SAMSØE}

Antropologien har siden tidernes morgen bidraget til forståelser af samspillet mellem teknologi og samfund, og hvad der sker, når nye teknologier introduceres.

Perspektivet har som oftest været analytisk, distanceret og ikke mindst magtkritisk. Som der også står i invitationen til dette temanummer, har ,flere antropologer med inspiration fra videnskabs- og teknologistudier (Science and Technology Studies) forholdt sig kritisk til magtfulde former for viden og praksis, som i sig selv er med til at skabe verden på bestemte måder og favorisere og/eller marginalisere bestemte sociale grupper og livsformer".

Gennem den forskning har vi lært, hvordan teknologier redistribuerer viden og magt mellem forskellige aktører, hvordan den forstærker muligheder for kontrol og styring - eller gør det modsatte. Forskerne har været optaget af tilblivelsen af teknologier, det vil sige, hvordan teknologier bliver til og formes, når de bruges af aktører med særlige interesser i konkrete kontekster.

Nogle gange er tilgangen nysgerrig og forsøgsvis neutral, men ikke sjældent bliver den magtkritisk. Det foucaultske blik på magt og styringsteknologier træder ind på scenen: Det potentielt problematiske og risikoen for en styring får hovedrollen, fordi styring kan føre til ensretning, disciplinering, overvågning, kontrol og straf. Som antropologer, der arbejder med indførelse og forskning i en ny social teknologi, møder vi indimellem det magtkritiske blik hos både forskerkolleger og informanter, når de stiller spørgsmål til konsekvenserne af den teknologi, vi arbejder på at indføre.

I denne position reflekterer vi kritisk over kritikken. Vi argumenterer for det frugtbare $i$ at engagere sig aktivt $i$ de teknologiske tilblivelsesprocesser frem for alene at forholde sig kritisk observerende. Antropologer kan med afsæt i indsigter i samspillet mellem teknologi, viden og samfund søge at påvirke og bidrage til de processer af mægtiggørelse, som tilblivelsesprocesserne omkring ny teknologi rummer potentialer for. 


\section{Vores position}

Denne position skrives fra en særlig position. En position som forsker og projektleder for et stort studie af, hvordan en ny indsats med nye redskaber i socialt arbejde kan gennemføres i praksis. ${ }^{1}$ Som sådan er vi på én gang i færd med at implementere en ny social teknologi i otte kommuner og forske i, hvad der sker, når teknologien tages i brug. Vores position er tværfaglig, men vi har antropologien og videnskabs- og teknologistudier som teoretisk rammeforståelse.

Den sociale teknologi, vi implementerer, har vi selv været med til at udvælge. Vi har formet den og gjort den klar til implementering efter bedste evne i tæt dia$\log$ med aktører fra det felt, vi arbejder i. Som sådan har vi fra begyndelsen indtaget en normativ position: Vi har stillet os sammen med dem, som vurderer, at sociale teknologier, der baserer sig på evidens og forskningsbaseret dokumentation, er værd at udbrede til praksis. Forskningspositioner er, som de fleste andre positioner, ikke neutrale.

\section{Positioner i feltet}

Feltet, vi arbejder i, oser af magt. Vi er i kommunernes socialforvaltninger, der, hvor børn anbringes i plejefamilier, når kommunen vurderer, at forældrene ikke kan varetage opgaven.

Feltet er kendetegnet af magtfulde aktører: socialarbejdere, hvis vurderinger kan føre til, at børn anbringes, at de kommer hjem igen, eller at de anbringes et nyt sted.

Det er et felt, som benytter en vifte af magtfulde sociale teknologier: journaler, handleplaner, lovpligtige halvårlige opfølgningssamtaler, børnesamtaler, skoleudtalelser. For blot at nævne nogle af de væsentligste sociale teknologier, der på én gang har til formål at understøtte socialarbejderens arbejde og sikre borgerens ret til at blive hørt og medinddraget, men som helt overordnet kan siges at være magtfulde i kraft af den viden, de indsamler og udvælger.

Det er samtidig et felt med udsatte aktører, som er dybt afhængige af socialarbejdernes vurderinger - og af de herskende forståelser, der sættes i spil.

I denne gruppe møder vi forældrene, hvis børn fjernes fra hjemmet. Siden Graversen-betænkningen fra $1990^{2}$ har det været en herskende forståelse, at børns tilknytning til deres biologiske forældre er central for deres udvikling. I det perspektiv er barnets forældre principielt bedst til at give barnet omsorg, men såfremt forældre ikke kan tage vare på barnet $\mathrm{i}$ hverdagen, fordi de har egne problemer, kan det blive nødvendigt, at staten griber ind. At sætte barnet i pleje kan derfor anses som en midlertidig foranstaltning, der varer, indtil forældrene făr 
løst de problemer, der forhindrer dem i at give barnet omsorg. Derfor bør barnet så vidt muligt have jævnligt samvær med forældrene og hjemgives, så snart socialforvaltningen og en forælder er enige om, at han eller hun kan påtage sig opgaven igen. Med denne logik som fremherskende bliver et væsentligt tema i feltet uvægerligt, hvornår et barn skal hjemgives til forældrene. Og den viden, som indhentes og lægges i journaler i socialforvaltningen, bliver en central aktør i den forhandling.

I gruppen af udsatte aktører møder vi selvsagt også børnene. De oplever sig ofte ikke hørt. De har sjældent stor tillid til de skiftende sagsbehandlere, som hvert halve år spørger dem til deres trivsel. De ældre af dem er sig smerteligt bevidste, at det, de siger, og måden, det forstås på af socialarbejderen, kan have vidtrækkende konsekvenser for deres liv. Hvor de skal bo. Hvor de skal gå i skole.

Endelig møder vi plejeforældrene. Når et barn sættes i pleje, overtager plejeforældrene forældreopgaven. Det betyder, at de bliver barnets primære omsorgsgivere og dem, der har det daglige ansvar for, at det trives og lærer på alderssvarende niveau. Det er en (anden) herskende forståelse, at det kræver særlige kompetencer, som man ikke kan forvente af den almindelige forælder. Børnene har nemlig en forhistorie med omsorgssvigt, skoleskift og for nogle også mishandling, og de har derfor ofte psykiske vanskeligheder og er bagud i skolen. Det er i det perspektiv centralt for den anbringende myndighed at sikre sig, at plejefamilien har de særlige kompetencer, der skal til, for at sikre barnets trivsel. Det kan de sikre gennem supervision og efteruddannelse. De kan sikre det ved at give den særlige ekstraordinære støtte, der skal til. Eller de kan flytte barnet til en anden plejefamilie. Denne forståelse har naturligvis sine egne konsekvenser for samspillet mellem aktørerne og de sociale teknologier, der bruges til at følge et barns trivsel.

\section{En ny social teknologi i feltet}

I dette felt indsætter vi med vores projekt en ny social teknologi. Teknologien består i systematiske gentagne målinger med to anerkendte og validerede spørgeskemaer, hvor lærere, plejeforældre og ældre børn svarer på, hvordan de ser barnets styrker, vanskeligheder og eventuelle læringsudfordringer. Skemaerne supplerer de oplysninger om barnets læring og trivsel, som sagsbehandlere og familieplejekonsulenter i forvejen indhenter hvert halve år, men hvor skoleudtalelser, børnesamtaler og opfølgningssamtaler normalt følger en løst struktureret dagsorden, stiller spørgeskemaerne de samme afgrænsede og konkrete spørgsmål til alle.

Spørgeskemaerne følges af en automatiseret analyse, i hvilken svarene om det enkelte barn sammenlignes med svar for typiske danske børn. På den måde 
fungerer spørgeskemaerne som et måleinstrument på linje med et termometer. Målingen viser, om barnet er i normalområdet, eller om barnet vurderes at have forhøjet grad af mistrivsel eller læringsudfordringer.

Man kan spejle denne teknologi i kritiske studier af andre måleinstrumenter. Med det kan man spørge, om instrumentets snævre sammenlignende og talbaserede analyse vil erstatte en bred socialfaglig vurdering baseret på plejeforældre, lærere og børns beskrivelser. Om dens karakter af måleinstrument skaber forestillinger om en anden uanfægtelighed eller sandhedsværdi end det talte ord.

Man kan kritisere, at spørgeskemaer designes ved at udvælge konkrete spørgsmål, som på den måde styrer opmærksomheden mod bestemte forhold. Dermed kan spørgeskemaer potentielt udelukke væsentlige andre forhold, nemlig dem, som der ikke spørges til.

Man kan anfægte spørgeskemaernes tilsyneladende neutrale indpakning og fremføre, at alle spørgsmål, der stilles til mennesker, skaber noget i sig selv. Så hvad skaber det da at spørge voksne og ældre børn om børnenes potentielle psykiske mistrivselssymptomer og indlæringsvanskeligheder? Hvad skaber det at journalisere og gemme den viden? Kommer vi til at bidrage til endnu mere magtudøvelse over de udsatte børn, som vi dybest set ønsker at hjælpe?

Man kan tænke sig til et væld af potentielle konsekvenser af at bruge de to spørgeskemaer systematisk i arbejdet med at følge børns læring og trivsel, som fra et magtkritisk perspektiv er problematiske.

Men når skemaerne reelt tages $\mathrm{i}$ brug, kan der ske alt muligt andet. Vores første pilotafprøvninger viser, at de potentielle konsekvenser af at tage skemaerne i brug rækker langt ud over, hvad vi kunne tænke os til fra en distanceret magtkritisk position.

\section{Ny teknologi som potentielt middel til mægtiggørelse}

Vores projekt er i sin spæde opstart. Vi har blot afprøvet spørgeskemaerne på få personer. Responsen fra de personer er imidlertid interessant.

Nogle plejeforældre følte sig hørt bedre. De fortæller, at det er godt at få ,papir pä“. For de oplever, at karakteren og omfanget af barnets trivsel - eller mistrivsel bliver tydelig gennem skemaet. Når deres vurdering fremstod så tydeligt på skrift og som måling, kunne de få socialarbejderen til at forstå, hvor skidt deres plejebarn faktisk havde det. Det blev et argument for behovet for ekstraordinær hjælp. Generelt oplevede de en bedre og mere dybdegående rådgivende samtale end den, de plejede at have, når de havde sparringsmøde med en socialarbejder. De oplevede en større grundighed og systematik. Spørgsmålene i skemaet tvang alle til at rette opmærksomheden mod barnets trivsel og læring. „Det gør, at man 
tænker over tingene. Det er en udmærket opfølgning i forhold til hverdagen,“ som en plejemor sagde.

Det var også socialarbejdernes oplevelse. Som en sagsbehandler sagde: „Der, hvor det giver os rigtig, rigtig meget, det er ved dem [plejeforældre], der trækker lidt på skulderen og siger, 'det går vel fint nok'. "En sagsbehandler vurderede det bydende nødvendigt at få alle børns vurderinger af deres egen trivsel og læring $i$ et format, som gjorde, at det var enkelt at sammenligne med resultaterne fra de voksnes spøgeskemabesvarelser. Kun derigennem kunne hun sikre sig, at barnets stemme blev hørt, når hun skulle lave handleplaner efterfølgende.

En læringskonsulent fandt det befriende, at man gennem spørgeskemaet om læring kunne få lov at spørge til - og derfor tale om - det, som ikke gik så godt. I en pædagogisk virkelighed med stort fokus på at se børns styrker og tale om det, der går fremad, oplevede hun, at alt for mange børns læringsudfordringer røg under radaren i den almindelige skole-hjem-samtale.

Respons som denne gjorde os opmærksomme på, hvordan den nye teknologi potentielt også kan skabe mægtiggørelse, skabe nye former for dialoger, forstærke nogle herskende forståelser og ændre andre.

- Vi blev opmærksomme på, at spørgeskemaerne ændrer på, hvem der kommer til orde i journalen. Hidtil har det skrevne ord i journaler og handleplaner været socialarbejderens - baseret på hendes fortolkninger og vurderinger. Med spørgeskemaerne ender plejeforældre og læreres ord også i journalen, om end kun inden for de afgrænsede spørgsmål, som stilles i skemaerne.

- Vi blev opmærksomme på, hvor betydningsfuldt det kan være, hvis en måling kan bruges som potentielt argument for at få bevilget støtte til et barn, fordi det ellers kan være vanskeligt at få bevilget.

- Vi fik øje på, at det bliver afgørende for både forældre og plejeforældre, hvilken herskende forståelse af anbringelsen og forældres og plejeforældres respektive roller, som den nye sociale teknologi bindes op på. De herskende forståelser er afgørende for, hvordan teknologien påvirker samspillet mellem aktørerne. Hvis målingerne sætter fokus på trivslen og indsatsen i plejefamilien, hvad efterlader det så af plads til fokus på vejen til hjemgivelse? Hvilken herskende forståelse vil teknologien fremme? Vi ved det ikke endnu, men vi ved, at det er af overordentlig stor betydning for aktørerne i feltet.

- Vi er blevet opmærksomme på, hvordan formen af en besvarelse er magtfuld - og at vi kan være med til enten at understøtte eller underminere barnets stemme gennem den form, vi anbefaler, at svarene fra et barn indhentes og dokumenteres i.

- Endelig har vi set, hvordan spørgsmål i spørgeskemaer nok afgrænser, men også skaber muligheder for at tale om noget, som der ellers ikke tales om, for- 
di det ikke passer ind i de herskende forståelser og tilgange, der ellers præger samtalerne.

Ovenstående er enkle eksempler. Tiden er ikke inde til at drage konklusioner. Vi ved ikke, om den ny teknologi, vi indfører, i sidste ende gavner børnene. Vi ved ikke, hvilke konsekvenser den får. Teknologiens tilblivelse er kun i sin vorden. Vi ved imidlertid, at det gør en forskel, hvor vi som antropologer positionerer os i tilblivelsesprocessen.

\section{Hvad kan antropologer give til teknologiske tilblivelsesprocesser?}

Vi kan blive stående på afstand og kritisk spørge til, hvorvidt og hvordan den nye teknologi muliggør mere styring.

Vi kan også følge processen tæt. Nysgerrigt se, hvad der faktisk sker, når teknologien omformer samtaler, redistribuerer fordelingen af viden, hvad der bliver plads til i samarbejdet, og hvad der lades ude.

Men vi kan også indgå i processen. Bruge vores indsigter i samspillet mellem teknologi, viden og samfund til aktivt at påvirke den nye teknologis tilblivelsesproces. Det er det, vi er i færd med. Vi kan ikke styre processen. Vi kan ikke forudse, hvad der kommer til at ske. Men vi kan involvere os i det. Aktuelt gør vi det gennem facilitering af møder, gennem undervisning, ved at skrive vejledninger til brugen af spørgeskemaer og samtaler, ved at tilbyde os som sparringspartnere for socialarbejderne, når de tager den nye teknologi i brug, og ved at lave informationsvideoer til børn. På den måde kan vi gå ind som aktører i processen.

Vi kan skabe åbne dialoger i feltet om, hvad der sker i tilblivelsesprocessen: hvem der favoriseres, hvad der synes at skydes til side, hvad der er hensigtsmæssigt set fra hvis synspunkt. Den analyse er ikke kun interessant stof for andre antropologer, der kan læse om det i forskningsartikler efter et projekts afslutning. Det er i høj grad viden, der er interessant undervejs i tilblivelsesprocessen og for dem, som deltager i den, som berøres af den nye teknologi, og som er med til at forme den.

\section{Hvad kan en aktiv involvering i teknologiske tilblivelsesprocesser give antropologen?}

Når vi aktivt engagerer os i tilblivelsesprocessen, bliver vi nødvendigvis normative. Vi bliver akut opmærksomme på, at alle udfald af processen ikke er lige gode. Vi har en holdning til, om det er godt eller skidt, hvis spørgeskemabesvarelser ender med at blive brugt som argument for at fjerne et plejebarn fra en 
plejefamilie. Vi har en holdning til, om det er godt eller skidt, hvis spørgeskemaerne medfører, at plejeforældre og skolelæreres vurderinger får en stærkere plads i socialforvaltningens samlede vurdering af et barns trivsel og læring. Vi bliver tvunget til at finde løsninger på det, som ellers kan udvikle sig negativt set fra vores position, og det gør os meget bevidste om både socialarbejdernes, plejeforældrenes, børnenes og vores egne problemforståelser.

Som sådan fordrer involveringen af os, at vi udvider vores refleksion over mulige ståsteder. Ved at flytte os fra en neutral forskerposition til en engageret forskerposition tvinges vi til at være del af en proces, som åbner vores øjne for endnu flere samspil. Som deltagere i processen mærker vi den. Vi mærker, at den ikke er lige meget. At det er godt at være magtkritisk, men det er bedre, hvis man kan bruge den indsigt til at bidrage til at mægtiggøre mennesker i udsatte positioner, når indførelsen af nye sociale teknologier muliggør det.

\section{Noter}

1. Studiet gennemføres i forsknings- og udviklingsprojektet „Mig og min plejefamilie“, der har til formål at styrke familieplejeanbragte børns trivsel og læring. Projektet gennemføres af forskere ved Nationalt Videncenter om Udsatte Børn og Unge (NUBU), og det finansieres af TrygFonden og Den A.P. Møllerske Støttefond.

2. Betænkning om de retlige rammer for indsatsen over for børn og unge, betænkning nr. 1212, 1990. Udarbejdet på baggrund af et udvalgsarbejde ledet af professor Jørgen Graversen. 